\title{
Flexibilization, Globalization, and Privatization: Three Challenges to Labour Rights in Our Time
}

Katherine V.W. Stone

Follow this and additional works at: http://digitalcommons.osgoode.yorku.ca/ohlj

Part of the Labor and Employment Law Commons, and the Labor Relations Commons Article

\section{Citation Information}

Stone, Katherine V. W.. "Flexibilization, Globalization, and Privatization: Three Challenges to Labour Rights in Our Time." Osgoode Hall Law Journal 44.1 (2006) : 77-104.

http://digitalcommons.osgoode.yorku.ca/ohlj/vol44/iss1/4 


\title{
Flexibilization, Globalization, and Privatization: Three Challenges to Labour Rights in Our Time
}

\begin{abstract}
Three dynamics are coalescing to reshape labour relations in the twenty-first century in the United States: They are flexibilization, globalization, and privatization. Flexibilization refers to the changing work practices by which firms no longer use internal labour markets or implicitly promise employees lifetime job security, but rather seek flexible employment relations that permit them to increase or diminish their workforce, and reassign and redeploy employees with ease. Globalization refers to the increase in cross-border transactions in the production and marketing of goods and services that facilitates firm relocation to low labour cost countries. And privatization refers to the rise of neo-liberal ideology, the attack on big government and the dismantling of the social safety net that have dominated public policy in the United States in recent years. All three of these dynamics have been detrimental to U.S. employment standards and union strength. This article describes how each of these dynamics has undermined labour rights and then asks, what prospects are there, in light of this environment, for protecting employment rights, re-invigorating unions, and securing a social safety net? The author answers by pointing to the many areas of social life in which the spread of the global leads to the reemergence. of the local. She argues that the response to the global threat to labour standards lies in a revival of collective action at the local level. She further contends that the combined forces of flexibilization, globalization, and privatization make collective action at the local level not only necessary, but also possible.
\end{abstract}

Keywords

Employee rights; Globalization; Privatization; United States 


\title{
FLEXIBILIZATION, GLOBALIZATION, AND PRIVATIZATION: THREE CHALLENGES TO LABOUR RIGHTS IN OUR TIME ${ }^{\odot}$
}

\author{
KATHERINE V.W. STONE*
}

Three dynamics are coalescing to reshape labour relations in the twenty-first century in the United States: They are flexibilization, globalization, and privatization. Flexibilization refers to the changing work practices by which firms no longer use internal labour markets or implicitly promise employees lifetime job security, but rather seek flexible employment relations that permit them to increase or diminish their workforce, and reassign and redeploy employees with ease. Globalization refers to the increase in cross-border transactions in the production and marketing of goods and services that facilitates firm relocation to low labour cost countries. And privatization refers to the rise of neo-liberal ideology, the attack on big government and the dismantling of the social safety net that have dominated public policy in the United States in recent years. All three of these dynamics have been detrimental to U.S. employment standards and union strength.

This article describes how each of these dynamics has undermined labour rights and then asks, what prospects are there, in light of this environment, for protecting employment rights, re-invigorating unions, and securing a social safety net? The author answers by pointing to the many areas of social life in which the spread of the global leads to the reemergence of the local. She argues that the response to the global threat to labour standards lies in a revival of collective action at the local level. She further contends that the combined forces of flexibilization, globalization, and privatization make collective action at the local level not only necessary, but also possible.
Aux États-Unis, trois dynamiques s'unissent pour donner une nouvelle forme aux relations dans le domaine du travail au $\mathrm{XXI}^{\mathrm{c}}$ siècle : il s'agit de la flexibilisation, de la mondialisation et de la privatisation. La flexibilisation se rapporte à l'évolution des pratiques de travail, où les entreprises ne recourent plus aux marchés internes de main-d'œuvre et ne promettent plus implicitement aux employés la sécurité à vie de leur emploi, mais recherchent plutôt des relations de travail souples qui leur permettent d'augmenter ou de diminuer leurs effectifs, ainsi que de réaffecter et redéployer leur personnel avec facilité. La mondialisation se rapporte à l'augmentation des transactions transfrontalières en matière de production et de commercialisation de biens et de services, laquelle facilite la délocalisation des entreprises vers des pays où la main-d'œuvre est bon marché. La privatisation se rapporte à la montée de l'idéologie néo-libérale, l'attaque contre les structures gouvernementales et le démantèlement du système de protection sociale qui, ces dernières années, dominent la politique publique américaine. Ces trois dynamiques ont porté atteinte aux nomes du domaine du travail et à la puissance des syndicats aux États-Unis.

Cet article explique comment chacune de ces dynamiques a miné les droits du travail. Il demande ensuite quelles sont les perspectives, au vu d'un tel contexte, pour protéger les droits des travailleurs, donner une nouvelle vigueur aux syndicats, et assurer un système de protection sociale. L'auteur répond en signalant les nombreux domaines de vie sociale où la diffusion du mondial amène la réémergence du local. Elle avance que la réaction à la menace mondiale qui pèse sur les normes en matière de main-d'œuvre dépend d'un renouveau de l'action collective au niveau local. En outre, elle affirme que, conjuguées, les forces de flexibilisation, mondialisation, et privatisation rendent l'action collective au niveau local non seulement nécessaire, mais également possible

2006, K.V.W. Stone.

* Professor, UCla School of Law, Los Angeles, California. 
I. PRESSURES SHAPING THE EMPLOYMENT RELATIONSHIP.
A. Flexibilization.
B. Globalization.
C. Privatization
D. The Three-Headed Beast.

II. THE LOCAL AS A COUNTERWEIGHT TO THE GLOBAL .90
A Globalization Versus Agglomeration:
The Gravitational Pull of the Local.
B. The Cult and Cultivation of Human Capital.
C. Shifting Social Policy From the National to the Local.

III. COLLECTIVE ACTION AT THE LOCAL LEVEL AROUND

ISSUES OF WORK AND SOCIAL CITIZENSHIP.

A. Examples of Citizen Unions in the United States ............................................ 97

1. Contingent Worker Groups and the

National Federation for Fair Employment...................................97

2. Local Living Wage Campaigns …………....................................... 98

3. The Industrial Areas Foundation and Project Quest ...................99

4. Justice for Janitors..................................................................... 101

5. WashTech and the Community Workers Association in Seattle101

B. Experiments in Regional Institutions in Europe ......................................... 103

IV. CONCLUSION 104

Flexibilization, globalization, and privatization are three dynamics that are coalescing to reshape labour relations in the twentyfirst century in the United States. Flexibilization refers to the changing work practices by which firms no longer use internal labour markets or implicitly promise employees lifetime job security, but instead seek flexible employment relations that permit them to increase or diminish their workforce and reassign and redeploy employees with ease. Globalization refers to the increase in cross-border transactions in the production and marketing of goods and services that facilitate firm relocation to countries that have low labour costs. And privatization refers to the rise of neo-liberal ideology, the attack on big government, and the dismantling of the social safety net that has dominated public policy in the United States in recent years. All three of these dynamics have been detrimental to U.S. employment standards and union strength. They are like Fluffy in the Harry Potter book, the vicious three-headed dog that guards the Philosopher's Stone.

This article describes how each of these dynamics has undermined labour rights. It then asks, what prospects are there for 
protecting employment rights, re-invigorating unions, and securing a social safety net? The answer lies in the proposition that the spread of the global leads to the re-emergence of the local. We see this in the area of culture, where the threat of global homogenization has spawned movements to preserve indigenous cultures and revive near-extinct languages all over the world. The revival of near-extinct languages is a testament to the will of many to retain their local individualities, cultures, and histories in the face of pressures for global convergence. Similarly the renaissance of indigenous people's art, music, and culture shows local spirit resisting global uniformity. So too, in the area of labour relations, the global begets the local. The response to the global threat to labour standards lies in a revival of collective action at the local level. Further, the combined forces of flexibilization, globalization, and privatization make collective action at the local level not only necessary, but also possible.

This article begins with a brief description of the three-sided onslaught on labour rights. It then shows how the three dynamics are interrelated in a way that raises new possibilities for effective action at the local level. The final section provides some examples of local initiatives that have emerged in response to Fluffy. These initiatives might point the way towards taming, if not slaying, the three-headed beast.

\section{PRESSURES SHAPING THE EMPLOYMENT RELATIONSHIP}

\section{A. Flexibilization}

In the twentieth century, most large corporations organized their workforces into what have been termed "internal labour markets." In internal labour markets, jobs were arranged into hierarchical ladders and each job provided the training for the job on the next rung up. Employers who used internal labour markets hired only at the entry level, and then used internal promotion to fill all the higher rungs.

\footnotetext{
' See Katherine V.W. Stone, From Widgets to Digits: Employment Regulation for the Changing Workplace (New York: Cambridge University Press, 2004) [Stone, From Widgets to Digits]; Claudia Dale Goldin, Understanding the Gender Gap: An Economic History of American Women (New York: Oxford University Press, 1990) at 247, n. 38 for a review of the economic literature on internal labour market institutions.
} 
Employers wanted employees to stay a long time, so they gave them an implicit promise of long-term employment and of orderly and predictable patterns of promotion. Consistent with internal labour market job structures, employers structured pay and benefit systems so that wages and benefits rose as length of service increased. ${ }^{2}$

Recently, employers have dismantled their internal labour market job structures and abandoned the implicit promises that went along with them. They now create new types of employment relationships that do not depend upon, or encourage, longevity. This gives employers flexibility to cross-utilize employees. It also allows for quick adjustments in production methods as firms confront increasingly competitive product markets. Work has thus become contingent, not only in the sense that it is formally defined as short-term or episodic, but also in the sense that the attachment between the firm and the worker has been loosened. The "recasualization of work" has reportedly become a fact of life all along the employment spectrum, from bluecollar workers to high-end professionals and managers. ${ }^{3}$

Changes in the employment relationship are reflected in the government employment data on job tenure and turnover. According to the Current Population Survey of the U.S. Bureau of Labor Statistics, there have been dramatic declines in job tenure between 1983 and 2002 among all men over the age of twenty, with the most significant declines among men in the age groups over forty-five. Between 1983 and 2002 there was a significant decline in the proportion of men who have been with their current employer for ten years or more. For men ages forty to forty-four, the percentage declined from 51 per cent in 1983 to less than 38 per cent in 2002. Similar large declines occurred for men in every age group over forty-five. ${ }^{4}$ These changes were largely among blue-collar

${ }^{2}$ See Katherine V.W. Stone, "Policing Employment Contracts Within the Nexus-ofContracts Firm" (1993) 43 U.T.L.J. 353, 363-69.

${ }^{3}$ See e.g. "The Future of Work: Career Evolution" The Economist 354:8155 (29 January 2000) at 89. See also Peter F. Drucker, Managing in a Time of Great Change (Oxford: Butterworth Heinemann, 1995); Rosabeth Kanter, On the Frontiers of Management (Cambridge: Harvard Business School Press, 1997) at 190; and Richard. Sennett, The Corrosion of Character (New York: W.W. Norton and Company, 1998) at 23. See generally Stone, From Widgets to Digits, supra note 1 .

\footnotetext{
${ }^{4}$ U.S., Department of Labour, Bureau of Labour Statistics, News Release, "Employee Tenure in 2002" (19 September 2002), online: BLS News Releases <ftp://ftp.bls.gov/pub/news.release/ History/tenure.09192002.news>.
} 
males who had a high school education or less. ${ }^{5}$ That is, the internal job structures that characterized the labour market experiences of the U.S. blue-collar male work force are fading. ${ }^{6}$

In addition to the empirical data, we know about the contemporary labour market from the accounts of journalists, scholars, and corporate executives. These informants report that there is a fundamental change in the implicit, psychological contract under which most Americans are now employed. For example, the sociologist Richard Sennett interviewed a number of younger employees about their experiences in the labour market, and reports:

The most tangible sign of that change might be the motto "No long term." In work, the traditional career progressing step by step through the corridors of one or two institutions is withering: so is the deployment of a single set of skills through the course of a working life. ${ }^{7}$

The changing employment patterns result from a series of new work practices that employers have instituted over the past decade. They include innovations such as broadbanding, designed to give employers flexibility to cross-utilize employees across job titles and departmental lines. They also include compensation practices such as pay-for-performance and benchmarking that attempt to match each employee's pay to their individual contribution and to their value in the external labour market. Other features of the new employment relationship are flattening the job hierarchy and increasing the discretion of lower ranks of employees. The latter trend is the result of a new appreciation of the role played by employee knowledge, skills, and imagination in firm success. Firms have designed various types of workforce empowerment programs to give. bounded discretion to relatively low-level employees in order to cultivate and capture employee knowledge, skills, and imagination. ${ }^{8}$

\footnotetext{
${ }^{5}$ Henry Farber, Are Lifetime Jobs Disappearing? Job Duration in the United States: 1973 1993, National Bureau of Economic Research Working Paper Series No. 5014 (Cambridge, MA: National Bureau of Economic Research, 1.995) at 16-20.

${ }^{6}$ For women, there was not such a marked decline, and in some cases there was even a modest rise, because women have not traditionally been part of the long-term employment system. However, the overall percentage of women working for ten years or more is significantly lower than men in any event. See ibid.
}

${ }^{7}$ Sennett, supra note 3 at 22.

${ }^{8}$ See generally Stone, From Widgets to Digits, supra note 1 at 87-113. 
The new employment relationship also involves a change in the implicit contract between the employee and the firm. Instead of giving employees an implicit promise of employment security, today's employers implicitly promise employability security-the ability to acquire skills that will enhance their opportunities in the labour market. Employers also no longer implicitly promise their employees orderly promotional opportunities. Rather, they promise opportunities for employees to network and gain skills that will prepare them for other jobs outside the firm. In the new "boundaryless" employment relationship, employees are expected to manage their own careers, rather than to expect long-term employment from a single firm. ${ }^{9}$

In many respects, unions in the United States are ill-suited to the emerging workplace. Many of the traditional practices of American labour are antithetical to the core ideas of the boundaryless workplace. For example, unions insist on using seniority to define promotional rights, and seek narrow definitions of job duties. Both of these practices are flatly inconsistent with the new employment practices. Seniority encourages and rewards longevity and worker-firm attachment rather than mobile, multi-employer careers. The new employment relationship de-emphasizes attachment, and instead stresses flexibility and crossutilization, features that are the very opposite of narrow job classifications and seniority-based work assignments. Unions also seek to obtain uniform standards for compensation and promotion. They seek to establish systems for job bidding that require employers to rely on internal promotion to fill openings and bumping rights along prespecified demotion paths during downsizing. These practices, like seniority, discourage cross-utilization within firms or divisions. Other union bargaining demands that are antithetical to the boundaryless workplace are scope clauses that keep work inside the bargaining unit and no-subcontracting clauses that keep work inside the plant. Unions attempt to draw tight jurisdictional lines around their certified bargaining-unit work by bargaining for provisions that require supervisors to refrain from performing unit work. These practices seek

\footnotetext{
${ }^{9}$ See generally Michael B. Arthur \& Denise M. Rousseau, The Boundaryless Career: A New Employment Principle for a New Organizational Era (New York: Oxford Univerity Press, 1996).
} 
to prohibit the very blurring of departmental and firm boundaries that characterizes the boundaryless workplace. ${ }^{10}$

The mismatch between today's flexible work relations and conventional union practices has led companies to resist unions more fiercely than ever. Indeed, unions have had a difficult time gaining a foothold in companies, such as TRW and Hewlett Packard, that have been at the vanguard of the new human resource revolution. Some companies, such as General Electric, engaged in an aggressive practice to deunionize first in order to restructure their labour relations. The move to flexible employment practices has thus been one of the factors feeding management's assault on unions.

At the same time, the new work practices have drained workplace-centred unions of much of their effectiveness. Under the present labour laws, unions represent a group of workers in a specifically defined bargaining unit. ${ }^{11}$ The terms and conditions they negotiate apply to jobs in the defined unit rather than to the individuals who hold the jobs. Yet, as discussed above, the new workplace is not job-centred nor is it made up of separable bounded departments. It involves cross-utilization, broadbanding, and other features of boundarylessness. Collective bargaining based on bargaining units means that as individual workers move between departments, units, or firms, their labour contracts do not follow them. In today's world of frequent movement, unionism based on bargaining units means that union gains are increasingly ephemeral from the individual's point of view.

\section{B. Globalization}

Globalization is the cross-border interpenetration of economic life. While we cannot see globalization directly, its imprint is evident in the spread of foreign plants across domestic landscapes, the telecommunications and computer technologies that enable firms to produce, distribute, and market all over the world, falling trade barriers, and the fading foreign exchange restrictions. National borders are becoming permeable to products made all around the globe and to global capital flows.

${ }^{10}$ See Stone, From Widgets to Digits, supra note 1 at 203-06.

${ }^{11} 29$ U.S.C. $\$ 159$ (a) (2000). 
Trade unionists and progressive policy-makers have long warned that the spread of globalization will mean the demise of hard-won labour standards and workplace rights in the Western world. ${ }^{12}$ There are considerable data that indicate that these fears are well founded. William Cooke analyzed data on foreign direct investment by U.S. multinational firms within the nineteen OECD countries between 19821993. He found that one of the most important factors in firm locational decisions within the developed world was that investment was negatively correlated with levels of unionization and protective labour legislation. ${ }^{13}$ In a similar vein, Richard Freeman and Ana Reganga found that increased trade between the United States and less developed countries between 1970-1992 led to significant reduction both in employment levels and wages for low-skilled workers in the United States. ${ }^{14}$ Further, Laura Tyson and Bill Cline have concluded that trade is responsible for somewhere between 20 and 53 per cent of the increase in income inequality in the United States. ${ }^{15}$ These findings are powerful evidence that companies are moving low-skilled jobs to low-wage, low union density countries, thereby depressing wages and increasing unemployment in their wake.

Some transnational institutions have been constructed to harmonize labour standards across borders, but they operate only in limited geographic areas and deal with only limited subjects. For example, the European Union has a complex multi-tier system for the harmonization of certain employment standards among its member countries. EU Directives address many issues of concern in the employment relationship, such as equal pay for part-time work, protections for workers during corporate insolvency, and health and

12 See Katherine V.W. Stone, "Labour and the Global Economy: Four Approaches to Transnational Labour Regulation” (1995) 16 Mich. J. Int'l L. 987 (citing sources) [Stone, “Labour and the Global Economy"].

${ }^{13}$ William N. Cooke, "The Influence of Industrial Relations Factors on U.S. Foreign Direct Investment Abroad" (1997) 51 Indus. \& Lab. Rel. Rev. 3.

${ }^{14}$ Richard Freeman \& Ana Reganga, "How Much Has LDC Trade Affected Western Job Markets?" (Paper presented to the ECARE/CPEII Conference on International Trade and Employment, Paris, 25 September 1995) in Mathias Dewatripont, André Sapir \& Khalid Sekkat, eds., Trade and Jobs in Europe: Much Ado about Nothing? (London: Oxford University Press, 1999).

${ }^{15}$ These studies are summarized in Robert Scott, "Alternatives to the Neo-Liberal Model that Address Differences Between North and South, and Labour and the Environment" (1998) Economic Policy Institute at 3-4. 
safety standards. However, the current EU regulations do not cover most issues of collective labour rights nor do they set specific labour standards in most areas. ${ }^{16}$ The Labour Side Agreement in the North American Free Trade Agreement (NAFTA) creates a system of crossborder monitoring that does not require countries to enforce any particular labour standard. It does, however, attempt to ensure that each country enforce whatever its domestic law happens to be. Some predict that this may become a widespread model for transnational labour governance. ${ }^{17}$

Globalization directly undermines domestic labour standards. It also does so indirectly by undermining the strength of domestic labour organizations. The specific ways in which globalization threatens labour are well known but worth restating briefly. ${ }^{18}$

First, globalization diminishes labour's bargaining power. As capital mobility increases, businesses tend to relocate to countries with lower labour standards. Further, when firms can relocate easily, unions have less power at the bargaining table in their home countries because they are always bargaining against the threat of relocation. This means that companies will be less likely to yield to union demands, and unions will not make demands out of fear of triggering business flight.

Second, globalization diminishes the level of domestic labourprotective regulations. Companies prefer to produce in legal environments that offer the least protections for labour and, when feasible, they shift production to capture the resultant lower labour costs. Thus, they engage in a labour standards "race-to-the-bottom." The prospect of races to the bottom places organized labour in a prisoners' dilemma: it wants domestic protective legislation to improve labour standards but is acutely vulnerable to the capital flight that increased labour standards can trigger. This dilemma is intensified as economic life becomes more global, rendering labour less effective as a political actor.

Third, globalization encourages regulatory competition. Regulatory competition occurs when nations compete for business using

\footnotetext{
${ }^{16}$ Katherine V.W. Stone, "To the Yukon and Beyond: Local Labourers in a Global Labour Market" (1999) 3 J. Small \& Emerging Bus. L. 93 at 108-11.

${ }^{17}$ Sir Bob Hepple, Labour Laws and Global Trade (Oxford: Hart, 2005).

${ }^{18}$ For further development of each of these issues see Stone, "Labour and the Global Economy," supra note 12 at $990-97$.
} 
lower labour standards to attract businesses. It leads non-labour groups to oppose labour regulation on the ground that business flight hurts them. Thus regulatory competition could trigger a downward spiral in which nations compete with each other for lower labour standards, and labour loses its historical allies at the domestic level, rendering it powerless to resist.

Fourth, runaway shops, races-to-the-bottom, and regulatory competition pit labour organizations in one country against those in another. Thus, while globalization could be an impetus toward international labour solidarity and cooperation, it can also lead to organizational fragmentation and dissension. One strategy unions in developed countries (DCs) have used to diminish the possibilities of domestic runaway shops and races-to-the-bottom is to advocate supranational legislation that would equalize labour standards. But unions in less developed countries (LDCs) have resisted these measures and attacked them as protectionist. ${ }^{19}$ Another possible union strategy is to attempt to organize workers across national and regional borders and bargain for parity. However, while such a strategy has succeeded at times within a single country, it is a problematic approach when corporations move beyond national boundaries. Countries have labour laws and collective bargaining systems that differ markedly from each other, even within the Western world. Thus it is difficult for unions in one country to collabourate with unions in other countries in a way that jointly harnesses their economic weapons and furthers their common bargaining goals.

Finally, globalization can lead to the deterioration of labour's political power. National labour movements operate in the context of a particular regulatory environment. Labour's political power is undermined when the locus of labour regulation moves from a national to an international arena.

\footnotetext{
${ }^{19}$ See Louise D. Williams, "Trade, Labour, Law and Development: Opportunities and Challenges for Mexican Labour Arising From the North American Free Trade Agreement" (1996) 22 Brook. J. Int'l L. 361 at 381 (arguing that developed and developing countries' unions have opposing interests, because LDC unions benefit from the influx of jobs); see also Karen Vassler Champion, "Who Pays For Free Trade-The Dilemma of Free Trade and International Labour Standards” (1996) 22 N.C.J. Int'l L. \& Com. Reg. 181 at 215-16.
} 


\section{Privatization}

A third trend that is reshaping labour relations is privatization, broadly defined. The term "privatization" is generally used to refer to policies that shift responsibilities and resources from the public sphere to the private sector. But it is useful to understand privatization as not merely the shift from the public to the private sector, but also the free market ideology that underlies the shift, in particular the neo-liberal assault on the New Deal social welfare state.

In the United States, the neoliberal assault on New Deal social policies has had two dimensions. First, it attempts to shift responsibility for social welfare out of the public domain and into the arena of private contract. Second, it attempts to move responsibility for social welfare away from the federal government and to the states. Both of these intellectual and political attacks on the New Deal have been garnering strength over the past twenty years.

Beginning around 1980, as the National Labor Board retreated from protecting union organizing, the core of social regulation devolved more and more to the states that had recently enacted a number of state employment laws protecting individual employees. ${ }^{20} \mathrm{At}$ the same time, changes in the pre-emption rules of labour law had the effect of undermining unions' contractual protections while strengthening protection for individual workers. ${ }^{21}$ The new era corresponded to a decline in labour's political power. In the 1990s, the trend continued with the rise of the "new federalism" in constitutional law and the continued dismantlement of the social welfare state of the New Deal. For example, in United States v. Morrison, the Court struck down the Violence Against Women Act on the grounds that it was not a valid regulation of interstate commerce. ${ }^{22}$

\footnotetext{
${ }^{20}$ Katherine V.W. Stone, "The Legacy of Industrial Pluralism: The Tension Between Individual Employment Rights and the New Deal Collective Bargaining System" (1992) 59 U. Chicago L. Rev. 575.

${ }^{21}$ For a detailed discussion of the changes in the pre-emption rules and their detrimental impact on union strength see $i b i d$.

22529 U.S. 598 (2000). There have also been a number of recent cases cutting back on federal power to impose anti-discrimination measures on the states. See e.g. Kimelv. Florida Board of Regents, $120 \mathrm{~S}$. Ct. 631 (2002). On the nature of the "new federalism" in the area of social regulation, see Robert C. Post \& Riva B. Siegel, "Equal Protection by Law: Federal Antidiscrimination Legislation After Morrison and Kimel' (2000) 110 Yale L.J. 441.
} 
The devolution of the site of regulation from the federal to the state level was accompanied by other neo-liberal policies. For example, the shifting in the responsibility for social welfare to the states and localities occurred at the same time that local anti-tax movements succeeded in enacting tax cuts and defeating local bond initiatives. This fiscal austerity constrained local governments' capacity to fund many social programs. As a result, social welfare programs have moved from the federal level to the states and localities where there are less resources to pay for them. This shift is in keeping with the neo-liberal agenda of shrinking the public sector. With increased responsibility for social welfare, state and local governments have to make hard choices between education and welfare, between street repairs and public health. All of these trends are a result of the neo-liberal ideological attack on the policies of the New Deal and the idea of a redistributive role for government. ${ }^{23}$

The shift from federal to state regulation and the rise of neoliberal ideology also involves shifting responsibilities and resources from the public sphere to the private sector. The impulse to move regulation from the public to the private domain is justified by a free market ideology that celebrates contract over regulation. One area where this has occurred is in the adjudication of violations of labour rights. Increasingly, employers are requiring employees to waive their rights to a public forum and agree instead to bring any claims of violations of labour rights to a private forum, a forum that is crafted and often controlled by the employer. The U.S. Supreme Court has upheld the use of private arbitration tribunals for adjudicating claims under the discrimination laws, and lower courts have upheld them for many other types of employment claims. ${ }^{24}$ Employment law is thus becoming a body of law that is interpreted by private arbitrators outside of the public eye. As employers move more and more disputes about labour rights out of public fora, the resolution of employment disputes becomes invisible and the decision makers become unaccountable. There also fails to

\footnotetext{
${ }^{23}$ These attacks are embodied in the current "constitution-in-exile" view of constitutional law. See e.g. Michael J. Gerhardt, "On Revolution and Wetlands Regulations" (2002) 90 Geo. L.J. 2143 at 2144-45; "Special Symposium Issue: The Constitution in Exile" (2001) 51 Duke L.J. 1 (containing articles for and against this view of the Constitution).

${ }^{24}$ Gilmer v. Interstate/Johnson Lane Corp., 500 U.S. 20 (1991); Circuit City Stores, Inc. v. Adams, 535 U.S. 1112 (2002).
} 
develop a body of publicly-known jurisprudence that can provide a normative basis for the assertion of labour rights by others. ${ }^{25}$

In the United States the ascendancy of neo-liberal public policies has had many ramifications, including dismantling welfare, easing environmental regulations, diminishing worker health and safety protections, diluting the right to organize unions, weakening the strike weapon, and reducing the funding for public education and health programs, to name just a few. One result is that regulatory competition has again become a serious concern. States aggressively compete for businesses by touting their low labour costs and union-free environment, thereby pressuring other states to lower their labour protections. For example, we are in the early phases of a movement sweeping the states to revise workers' compensation laws to reduce protection and compensation for injured workers.

\section{The Three-Headed Beast}

The triple onslaught of flexibilization, which has rendered many of the old labour market skills and institutions obsolete, globalization, with its propensity for geographic dispersion, and privatization under neo-liberal ideology, with its repudiation of social legislation at the national level, all contribute to union decline and a diminishment of labour rights. Flexibilization increases employers' incentive to avoid unions because they perceive unions as promoting rigidity, uniformity, job security protections, and narrow job definitions. Globalization increases employers' opportunities to avoid unions and labour regulations in their quest for lower labour costs. In addition, global production chains, enhanced transportation and communication, and lower trade barriers give employers considerable leverage to avoid unions or limit their effectiveness. The development of transnational global governance institutions also undermines the political strength of unions at the national level. Privatization fosters policies that diminish legal protection for labour rights and collective bargaining, and contribute to rapidly growing income inequality.

\footnotetext{
${ }^{25}$ For critiques of the use of private dispute resolution in employment relations, see Katherine V.W. Stone, "Mandatory Arbitration of Individual Employment Rights: The Yellow Dog Contract of the 1990s" (1996) 73 Denv. U.L. Rev. 1017.
} 


\section{THE LOCAL AS A COUNTERWEIGHT TO THE GLOBAL}

How can progressives and union groups respond to the threepronged onslaught caused by flexibilization, globalization, and privatization? Are there prospects for social progress in the midst of the above-described trends? Social progress can be defined as improvement in income distribution and provision of reasonable income and livelihood security for all members of our society. This is a minimalist vision-it does not describe complete equality nor total welfare support and insurance against all adversity. Rather, social progress means progress toward reasonable equality and a reasonably functioning social safety net to provide individual dignity, social justice, and a humane society.

If social progress is the goal, the question is, how can it be achieved? As stated earlier, globalization begets localization. The more homogeneous and cosmopolitan the world, the more some groups embrace and assert their local particularities and distinctive cultures. Globalization not only breeds a desire for localization, it also breeds new means to accomplish it. For example, the Internet is a rich terrain for local groups to keep their cultures alive and build new networks and connections that reflect their own particular shared values. A simple Google search for the term "Gaelic" revealed over three million. Web sites brimming with information about Gaelic societies, Gaelic schools, Gaelic dictionaries, Gaelic music groups, Gaelic Bibles, as well as many sub-languages such as Scottish Gaelic, Manx Gaelic, Irish Gaelic, Cymraec, and others. These sites give individuals of Gaelic origin the ability to connect, network, learn about their ethnic past, build on shared interests, and develop programs to keep their cultures alive. Similarly, while the dynamics of flexibilization, globalization, and privatization weaken labour rights, they also contain features that could make a revitalized progressive movement possible.

A. Globalization Versus Agglomeration: The Gravitational Pull of the Local

While corporations have a tendency to leapfrog across the globe, jumping over any country that imposes burdensome labour regulations, some corporations have a gravitational pull toward a particular place. Regional economists and economic geographers have found that certain types of firms want to locate near others that produce in their same field 
in order to take advantage of what they call "agglomeration economies" that exist in specific regional locales. ${ }^{26}$ These findings suggest that there might be a pull toward staying in place that is in tension with globalization's pull toward dispersion. If so, it might be possible for local policy-makers to develop local and regional institutions that facilitate the development of good jobs and sustainable economic growth. That is, globalization is not a one-way juggernaut, but rather it is a process that exists in tension with local embeddedness.

Economists became interested in the effect of agglomeration on economic growth in the 1980s. It had long been noted that firms producing certain types of goods and services were likely to locate near others of their type, such as the diamond district on 47th Street in New York City or the clusters of used car lots found in most small cities. ${ }^{27}$ Paul Krugman observed that 80 per cent of the industrial carpet in the United States was produced in Dalton County, Georgia. That and similar producer clusters, he said, could not be explained by neoclassical economic theory. ${ }^{28}$ This led economists to hypothesize that when certain types of firms were located in proximity to one another, they all received value from agglomeration that was independent of any single firm's contribution. A great deal of empirical work has since confirmed the existence of agglomeration economies that play a powerful role in the locational choices of firms ${ }^{29}$ One well-known study is Anna Lee Saxenian's description of the dramatic effects of agglomeration in the Silicon Valley computer industry. ${ }^{30}$ Other examples of successful localized agglomeration economies are the clusters of biotechnology firms around Princeton, New Jersey, of banking and financial firms in New York City, and of computer hardware manufacturing firms around Austin, Texas.

${ }^{26}$ See generally Edward L. Glaeser, "Are Cities Dying?" (1998) 12:2 J. of Econ. Persp. 139.

${ }^{27}$ See generally John M. Quigley, "Urban Diversity and Economic Growth" (1998)·11:4 J. Econ. Persp. 127 at 132 (describing studies).

${ }^{28}$ Paul Krugman, Geography and Trade (Cambridge, MA: MIT Press, 1991) at 59.

${ }^{29}$ See e.g. Matthew P. Drennan, "National Structural Change and Metropolitan Specialization in the United States" (1999) 78 Papers in Regional Sci. 297 at 314-15 (describes an empirical study finding agglomeration economy in information-intensive industries in urban areas). See generally Glaeser, supra note 26 at $148-50$ (citing studies).

${ }^{30}$ Regional Advantage: Culture and Competition in Silicon Valley and Route 128 (Cambridge, MA: Harvard University Press, 1994). 
Regional economists attribute many of the positive effects of agglomeration economies to the skills and knowledge that are concentrated in, and shared among, the locality's work force. ${ }^{31}$ Through networks built in informal gatherings in bars and coffee houses, workers share information about jobs, firms, and the specifics of their work. This "job talk" enables them to increase their knowledge about their work and enhance their own labour market prospects. The knowledge-sharing means that new ideas are constantly transmitted through the local "job talk" grapevine, eventually ending up informing the work itself. Also, each time workers change jobs, they broaden their knowledge of work techniques and practices in their field. Knowledge-sharing leads to innovation and to more highly trained workers. Thus, in an agglomeration economy, the availability of a trained, knowledgeable work force generates a culture that continually and seamlessly trains new employees, updates existing employees' skills, and provides firms with innovative ideas. ${ }^{32}$

The significance of agglomeration effects for firms and for local economic development has been a fertile subject of discussion amongst planners, regional economists, and economic geographers in recent years. What has eluded attention to date is the significance of agglomeration economies for labour. Yet to the extent that the choice of location of firms is influenced by the prospects of valuable agglomeration effects, firms will be less likely to move overseas, or across the country, to escape rising labour costs. Because the fuel on which agglomeration economies run is the store of knowledge residing in the local workforce, the workers in the locality have considerable leverage to pressure firms at the local and regional level.

\section{B. The Cult and Cultivation of Human Capital}

Firms today operate on the basis of a belief that the knowledge possessed by their employees is one of their major assets and a primary source of competitive advantage. In the words of Fortune magazine

\footnotetext{
${ }^{31}$ See generally John McDonald, Fundamentals of Urban Economics (Upper Saddle River, NJ: Prentice Hall, 1998).

${ }^{32}$ See e.g. Rosemary Batt et al., Net Working: Work Patterns and Workforce Policies for the New Media Industry (Washington: Economic Policy Institute, 2001); Saxenian, supra note 30 at 150 .
} 
editor Thomas Stewart, "Information and knowledge are the thermonuclear competitive weapons of our time." ${ }^{.33}$ The new flexible work practices are designed, in large part, to cultivate the intellectual engagement and abilities of employees and harness them on behalf of the firm. Employers' reliance on employees' knowledge and skill gives employees renewed leverage.

Firms want to enhance and utilize their employees' human capital, but they face a difficulty. Because they no longer use promises of job security as an inducement for employees to develop their skills, they need to find another way to align their employees' interests with their own. They do so by promising employees the opportunity to learn skills that can be used outside the firm, to build the employee's own career. Today's employees have a great interest in gaining human capital, not merely, or even primarily, to assist in their firm's success, but to enhance their own labour market opportunities. Employees, therefore, want to gain the kinds of general knowledge and expertise that they can take with them as they move from firm to firm in their own boundaryless careers.

Despite their reliance on employee knowledge, firms are reluctant to provide general training, at least on company time, because they cannot ensure that their employees stay in their employ indefinitely. ${ }^{34}$ Some companies provide training, but insist that new hires take the training on their own time, before they start work. Others rely on the outside market for training. Indeed, there has been an explosion of private training programs, many of which train in areas, such as airline reservation skills, that were previously taught on-the-job. There has also been an explosion in publicly funded job training through vocational education, community colleges, and other lifetime learning programs.

Firms also attempt to ensure that any knowledge an employee gains in the course of their employ is not utilized to the benefit of a competitor. Thus employers increasingly seek to impose postemployment restraints by insisting on covenants not to compete and bringing actions to protect trade secrets. As a result, there has been a

\footnotetext{
${ }^{33}$ Thomas A. Stewart, Intellectual Capital: The New Wealth of Organizations (New York: Currency/Doubleday, 1997) at ix.

${ }^{34}$ See Peter Cappelli, The New Deal at Work: Managing the Market-Driven Workforce (Boston: Harvard Business School Press, 1999).
} 
growing number of lawsuits over the enforceability of post-employment restrictive covenants and over the definition of trade secrets. ${ }^{35}$ The issue of who owns the employees' human capital is shaping up to be one of the most contentious in the field of employment law.

Employees and businesses have a shared interest in training a local labour force in the skills needed by local firms. Businesses need training to generate the human capital essential to the development of an agglomeration economy. Employees need training to retool and reposition themselves as they move in and out of jobs in a fluid labour market. For employees, training and retraining are key to enabling them to operate in the new flexible work environment. The central role of training for both firms and employees opens up opportunities for local activism and the development of local unions. Thus we might expect local unions to pressure businesses to contribute to public adult education and training programs. Already, the Workplace Investment Act attempts to foster local and regional training programs tailored to the needs of a locality's businesses. ${ }^{36}$

Community and worker groups can play a leading role in securing training and job opportunities. Collective action by grassroots groups to secure adult education and skills training could both expand employment opportunities for, and provide assistance to, those caught in the interstices of the boundaryless workplace. Training is an issue for which collective action can succeed and might make a difference. Training can help make a locality's workforce more flexible and skilled. But no individual employer has an incentive to establish such programs unilaterally because it cannot capture all the benefits for itself or prevent their capture by a competitor. However, if a group of workers, organized as a citizens' association or a local union, pressures firms in an area to contribute to a job training program, they would create a benefit in which all would share. Similarly, if enough corporations were induced to contribute to a locality's social infrastructure-its school system, hospitals, parks, cultural activities, and child care-this would

\footnotetext{
${ }^{35}$ Katherine V.W. Stone, "The New Psychological Contract: Implications of the Changing Workplace for Labor and Employment Law" (2001) 48 UCLA L. Rev. 519.

${ }^{36}$ See Nan Ellis, "Individual Training Accounts Under the Workforce Investment Act of 1998” (2001) 8 Geo. J. on Poverty L. \& Pol'y 235; see also Susan Saulny, "New Jobless Centers Offer More than a Benefit Check" New York Times (5 September.2001) A1. See generally Stone, From Widgets to Digits, supra note 1.
} 
help attract a highly skilled workforce who want quality educational opportunities for their children. Such community investment would benefit all firms in a locality. Thus the prospects of agglomeration economies combined with increased reliance by corporations on human capital could provide the glue to keep corporations in place. This could prevent them from bolting each time a citizen union demands that local firms adopt good corporate-citizen behaviour.

\section{Shifting Social Policy From the National to the Local}

The ascendancy of neo-liberal public policies has had many ramifications, including dismantling welfare, easing environmental regulations, diminishing worker health and safety protections, diluting the right to organize unions, weakening the strike weapon, and reducing funding for public education and health programs. One aspect of neoliberalism is the dismantling of the public sphere and the shifting of resources to the private sphere. In the private arena, actors lack accountability and decision-making processes lack transparency. However, as Ronen Shamir says, "When the public milieu becomes privatized, the private becomes a matter of public concern. ${ }^{.37}$ Hence, as more and more important issues are handled in the private domain, we are seeing emerging movements to monitor the deeds, and misdeeds, of the private sector. The public outcry over the Enron and other corporate scandals of the early 2000 s could be a harbinger of a new form of social awareness.

Privatization does not eliminate the role of the public sphere, but it changes its source and nature. Retrenchment in the public sector has entailed pushing governmental responsibilities onto the states and localities. Federal aid to localities is vanishing, and as a result, localities are being crushed by the weight of their obligations to provide education, health care, social welfare benefits, policing, and infrastructure. Local politics has become the terrain upon which social welfare battles must be fought. For this reason as well, it is imperative that there be organizations at the local level that represent the local working and non-working population in local political arenas. Those

\footnotetext{
37 "Between Self-Regulation and the Alien Tort Claims Act: On the Contested Concept of Corporate Social Responsibility" (2004) 38 Law \& Soc'y Rev. 635 at 635.
} 
arenas are increasingly becoming the place where economic and social policy is made.

\section{COLLECTIVE ACTION AT THE LOCAL LEVEL AROUND ISSUES OF WORK AND SOCIAL CITIZENSHIP}

If there are agglomeration economies to be had, it should be possible for unions and community organizations to capture some of the added value for the benefit of the community. The types of organizations that could most effectively achieve this are local and regional, cross-industry, cross-firm, labour, and community organizations. These organizations, which I call citizen unions, could bargain with employers in a geographic area for higher local minimum wages, uniform and portable benefits, child care, and job training and retraining programs. They could also serve as a political force to press for changes in labour and employment laws to provide higher levels of employment protection more generally. One sees the germs of such citizen union organizations in many places, including contingent worker groups and living wage campaigns that have emerged in many states, such as the Justice for Janitors organization in California and the Industrial Area Foundation in Texas.

Citizen unions could act at the local and regional level to pressure corporations to become good corporate citizens. Citizen unionism is animated by the proposition that because employers in a boundaryless workplace draw on the collective skills, knowledge, experience, and expertise of the local workforce, they should contribute to the welfare of that workforce generally. Employers should contribute to the local school systems, libraries, museums, cultural programs, sporting events, and hospitals. They should also fund educational programs for children. Corporate contributions of this sort would benefit all working people in the communities in which they operate.

A citizen union could be a potent force in the local political process. On the local level it could run candidates and push for legislation to provide some of the measures mentioned above, including portability of benefits, a local minimum wage, publicly funded wage supplements, publicly funded child care, and job training programs.

On the national level, a federation of citizen unions could lobby for measures that promote equality and justice in the workplace and in society more generally. It could press for anti-discrimination legislation, occupational safety and health protection, minimum wage increases, 
universal health insurance, and other worker protection measures. In addition, because a citizen union defines its members both as workers and as citizens of their locality, state, and nation, it can go beyond traditional labour issues and address issues of concern to working people more generally.

A number of local organizations have emerged in the United States in the past decade that embody some of the features described as citizen unionism. Here I will describe just a few, so that we can begin to see that the vision is not utterly fanciful.

\section{A. Examples of Citizen Unions in the United States \\ 1. Contingent Worker Groups and the National Federation for Fair Employment}

In many cities, groups have organized to press for rights for contingent workers in all types of workplaces. The Boston Center for Contingent Work (CCW) is one example. With support from Boston area unions and foundation grants, $\mathrm{CCW}$ uses media and other mechanisms to pressure companies that hire contingent workers to adopt codes of conduct that specify minimum rights and benefits. It has waged successful campaigns at trucking warehouses, retail stores, and tugboat operations. CCW is also active in lobbying the Massachusetts state legislature to enact a Workplace Equity Bill that would end discrimination in wages and benefits for contingent workers. To date, the bill has garnered significant support. ${ }^{38} \mathrm{CCW}$ also works with Boston area labour unions to encourage them to provide for wage and benefit parity for contingent workers in their collective bargaining agreements. ${ }^{39}$ In $2000, \mathrm{CCW}$ joined with contingent worker organizations from more than twenty-five cities to form the National Alliance for Fair Employment (NAFFE). NAFFE is lobbying to get temporary workers the same rights under the labour and employment laws as permanent employees. NAFFE has also proposed a Temporary Industry Code of Conduct, which would require temporary employment agencies to

${ }^{38}$ U.S., H. Res. 2105, The Workplace Equity Bill-An Act Regarding Workers in Contingent and Part-time Work, 2000. This bill was referred to the Committee on Public Safety, and hearings were held on 6 May 2005.

${ }^{39}$ See interviews of Tim Costello \& Gail Nicholson, Director \& Associate Director of Center for Contingent Work in Boston, Mass. (May 2000) [on file with author]. 
provide to workers written job descriptions, adequate safety equipment, on-site orientation, training, sick pay, holiday pay, health insurance rates, and transportation to work sites that are not publicly accessible. ${ }^{40}$ This Code further specifies that temporary workers may join unions at client employers if the existing collective agreement so permits. ${ }^{41}$ It also provides that " $[t]$ he agency will pay welfare-to-work participants a living wage consistent with local standards and benefits." ${ }^{.42}$

\section{Local Living Wage Campaigns}

In 1994, in Baltimore, members of the clergy joined members of the American Federation of State, County, and Municipal Employees (AFSCME) to do something about the problem of the working poor. Despite local economic development, there was a lot of poverty in the city. So they began to pressure the city to pay its employees higher wages. Ultimately they got the city to agree to require construction contractors who did business with the city to pay their workers a minimum wage sufficient to bring a family of four up to the federal poverty line. This entailed an increase in the minimum wage for those workers from $\$ 4.35$ to $\$ 7.70$. . $^{43}$

Since then, "living wage" campaigns have been mounted in many cities. Los Angeles passed an ordinance in 1997 that included more categories of workers and provided not only higher wages but also higher benefits. According to historian Stephanie Luce, "as of early 2002, 82 living wage ordinances are on the books, and approximately 70 campaigns are ongoing." ${ }^{44}$

The Baltimore living ordinance only applied to city construction workers, but over time other cities have expanded their scope to cover more types of workers. Some ordinances apply to firms that receive tax breaks as part of economic development strategies and firms that hold leases on city-owned properties. Some also cover direct city employees.

\footnotetext{
${ }^{40}$ See National Alliance for Fair Employment, "Contingent Workers Fight for Fairness" (May 2000), online: <http://www.fairjobs.org/fairjobs/contingent/cwffe.php>.

${ }^{41}$ Ibid.

${ }^{42}$ Ibid.

${ }^{43}$ Stephanie Luce, "The Full Fruits of Our Labor: The Rebirth of the Living Wage Movement" (2002) 43 Labor History 401 at 402-03.

${ }^{44}$ Ibid. at 403.
} 
And some cities have expanded the concept to impose a living wage on all private sector employers in a particular locality. For example, in Santa Monica, all large employers in the city's tourist zone are subject to the living wage ordinance. In 2002, New Orleans enacted a citywide minimum wage, set at a level that is considerably higher than the federal minimum. ${ }^{45}$ In 2003, San Francisco adopted a living wage ordinance, followed by the state of Nevada in 2004. In 2006, the minimum wage in Santa Fe went up to $\$ 9.50$ an hour. ${ }^{46}$

The movements to achieve city living wage laws are broad, geographically-based movements focused on issues of work. They are comprised of unions together with community organizations, church groups, organizations helping the homeless, women's groups, and other activists. The living wage campaigns often expand beyond the single issue of wages to require cities to pay for holidays and benefits, and to hire through community-operated hiring halls. Some also require the city to remain neutral in the case of a union organizing campaign. ${ }^{47}$

\section{The Industrial Areas Foundation and Project Quest}

The Industrial Areas Foundation (IAF) is a multi-issue organization that works at the grassroots level on local issues concerning social services, education, and employment. It has established organizations in a number of cities, including Chicago, Baltimore, Los Angeles, New York, and Boston, and has been particularly active in the Southwest. For example, in Texas, it has chapters in Dallas, Houston, Fort Worth, El Paso, San Antonio, and the Rio Grande Valley. The IAF's goal is to build broad-based coalitions that can exert pressure at the local and state level on issues such as job training, living wages, education, local economic development, health care, social services, and housing. Its members are not individuals, but rather churches, schools, unions, community groups, health centres, and other local organizations. It attempts to integrate concerns at the neighbourhood, family, and workplace level. The IAF organizing style is to identify leaders within existing organizations and teach them to mobilize others

\footnotetext{
${ }^{45} \mathrm{Ibid}$. at 404. at 40 .

${ }^{46}$ Jon Gertner, "What Is a Living Wage?" New York Times Magazine (15 January 2006) 38

${ }^{47}$ Supra note 43 at 404-07.
} 
and exert political power. It has had a number of successes and has become a potent political force in many cities. ${ }^{48}$

The IAF is involved in so many types of activities that it is impossible to catalogue them fully. Of particular interest for present purposes are the IAF activities in the labour market. In the early 1990s in San Antonio, the IAF developed an innovative job training program called Project QUEST. The program enrolled trainees in an eighteenmonth intensive skill-training course. It utilized local community colleges to provide the classroom instruction. It also secured commitments from 650 local businesses to provide jobs to the QUEST graduates. According to Paul Osterman, who evaluated Project QUEST for the Ford Foundation, the program "led to substantial gains for its participants, gains that far exceed that of typical training efforts." ${ }^{349}$ Osterman found that the program's graduates saw substantial enhancement in their earning power, and that the program provided other tangible benefits to the community. It led firms to raise their wage levels generally because QUEST insisted that participating employers pay trainees a living wage. The program also improved the community colleges because by working with QUEST, they were persuaded to revise their curriculum in a way that better reflected the needs of the labour market, in turn giving their students more marketable skills. ${ }^{50}$

The IAF has also been involved in workplace safety campaigns and living wage campaigns in numerous cities. In the Rio Grande Valley, it is currently attempting to build an employee association, which according to Osterman, will be a broad-based employee organization including all types of workers-low-wage workers, contingent workers, unemployed workers, public employees, semi-self employed, and fulltime workers. It plans a living wage campaign for health care workers, and hopes that the campaign will affect wage levels throughout the community. The association plans to offer training programs, job placement assistance, or other services to its members. However, it will not engage in collective bargaining. ${ }^{51}$

\footnotetext{
${ }^{48}$ For a thorough and insightful description of the history and current operation of the Industrial Areas Foundation, see Paul Osterman, Gathering Power: The Future of Progressive Politics in America (Boston: Beacon Press, 2002).

49 Ibid. at 163 .

${ }^{50}$ Ibid. at 163-64.

${ }^{5 l}$ Ibid. at $167-68$
} 


\section{Justice for Janitors}

The Service Employees International Union (SEIU) has been involved in innovative organizing drives in the building service area in several large cities since 1985. The first was in Los Angeles. Due to the unusual three-cornered employment relationship in which janitors work for building service companies that are themselves hired by building managers, economic pressure by janitors runs the risk of violating the secondary boycott laws. Instead of relying exclusively on economic weapons, the SEIU organized a direct appeal to the public for support. It marched in parades and participated in church events. It organized large public protests near, but not at, the buildings it was seeking to organize. In one case, the union staged a protest against the building used for the television show L.A. Law because the show used a non-union cleaning service. It also emphasized that one goal of the organizing drive was to gain health care coverage for janitors. In this way, it portrayed the organizing drive as a social justice movement in order to form alliances with other progressive elements in the community. The union also enlisted the help of community leaders to pressure the building owners by opposing permits for building projects. While the janitors were not strongly attached to any particular workplace, they were deeply embedded in the community and were able to use their community connections to assist in their organizing drives. ${ }^{52}$

\section{WashTech and the Community Workers Association in Seattle}

The Washington Alliance for Technology Workers (WashTech) is an example of a cross-workplace organization that involves workers with different types of skills within the same general industry. WashTech is a community-based membership organization that was founded in 1998. It was formed by a group of temporary workers at Microsoft, but has since expanded to include workers from Amazon.com and other high-tech companies. It currently includes lower- to middle-skilled technical workers in high-tech industries in the Seattle area. It has a Web page, a listserv, and a staff to address the labour-related issues of high-tech firms.

\footnotetext{
${ }^{52}$ Chris L. Erickson, et al., "Justice for Janitors in Los Angeles: Lessons from Three Rounds of Negotiations" (2002) 40 Brit. J. of Indus. Rel. 543.
} 
The WashTech Mission Statement states:

WashTech/CWA is an innovative and influential union whose members advocate for all technology workers in Washington State and beyond. We are a visionary community of activists and a leading voice for our members in the global economy. We help build economic security and fair working conditions through collective action, bargaining and legislative advocacy. ${ }^{53}$

Its goals are to address issues related to benefit portability, training, assistance with networking, concerns about non-compete covenants, and the problems of temporary work-many of the issues raised by the new employment relationship.

WashTech has attempted to engage in collective bargaining on two occasions, but each time the units it was seeking to organize were sold or moved overseas. As a result, the organization primarily focuses on two other features of unionism-providing mutual aid, and political action. For example, WashTech has set up a regional training centre in Seattle for high-tech workers that offers courses in many different programming techniques and web design skills. It also participates in a national training program that its affiliated union, the Communications Workers of America, has established with Cicso Systems. WashTech uses publicity to help high-tech workers resist non-compete clauses and helps them challenge the use of restrictive covenants. ${ }^{54}$ It also offers its members job listing services and training classes.

WashTech engages in extensive publicity and lobbying on behalf of temporary workers' interests. For example, it helped defeat a proposed law that would have eliminated overtime for computer professionals. It also lobbied successfully for a law to protect temporary workers in the public sector from misclassification or other attempts to deny them benefits they are entitled to under state law or collective bargaining agreements. Currently they are attempting to get legislation enacted that would force temporary employment agencies to inform their employees of their pay, work schedules, and other conditions of employment. ${ }^{55}$

\footnotetext{
53 For information about WashTech see online: WashTech: A Voice of the Digital Workforce <http://www.washtech.org> [WashTech]; see also Danielle D. van Jaarsveld, "Collective Representation Among High-Tech Workers at Microsoft and Beyond: Lessons from Wash Tech/CWA” (2004) 43 Indus. Rel. 364.

${ }^{54}$ Wash Tech, ibid.

${ }^{55}$ Wash Tech, ibid.
} 


\section{B. Experiments in Regional Institutions in Europe}

The European Union has also been engaged in experimentation with local solutions to global problems. In the past fifteen years, local and regional institutions have developed in Europe that are dedicated to protecting labour rights and at the same time to strengthening local economic opportunities. In some areas of Italy, Spain, the United Kingdom, and other countries, local and regional social pacts have been negotiated among tripartite institutions at the local level, empowering these areas to set labour-market policy. The pacts are typically negotiated not only by the traditional social partners-employer associations and trade unions-but also by civic groups and other organized local constituencies. They receive funding from the European Union structural funds as well as their national governments to invest in infrastructure and regional economic development. ${ }^{56}$ As Bruno Caruso writes, territorial employment pacts in Italy have fostered

territorial bargaining in the so-called economy of "districts"... which often correspond to
sectors traditionally featuring small firms or craftsmen (textiles, furniture, building,
tourism) ... . [Territorial bargaining has involved a] bilateral partnership but at a
territorial rather than industry or plant level, to support the competitiveness of micro
firms by injecting a heavy dose of flexibility (as regards working hours, wages and
geographic location) into both the internal and external labour market. These measures
are almost always accompanied by others supporting income levels if not permanent
employment security.

There is considerable debate about the effectiveness of these local forms of bargaining. However, many observers acknowledge that these forms of bargaining could improve local economic performance and provide employment protection to local populations. ${ }^{58}$

\footnotetext{
${ }^{56}$ For a detailed description of local social pacts in Europe see Ida Regalia, "Decentralizing Employment Protection in Europe: Territorial Pacts and Beyond" in Jonathan Zeitlin \& David M. Trubek, eds., Governing Work and Welfare in the New Economy: European and American Experiments (Oxford: Oxford University Press, 2003) 158 at 163-70.

57 “ Decentralised Social Pacts, Trade Unions and Collective Bargaining-How Labour Law is Changing" in Marco Biagi, ed., Towards a European Model of Industrial Relations? Building on the First Report of the European Commission (Great Britain: Kluwer Law International, 2001) 193 at 210 .

${ }^{58}$ Supra note 56.
} 


\section{CONCLUSION}

The U.S. organizations described above have all emerged independently over the past decade or two. Each focuses on making improvements for workers and communities at the local level. While they differ as to their tactics and organizational design, they all share some attributes of the proposed citizen union model. They demonstrate the truth of the observation that the best response to globalization is localization. Further, these organizations promote civic engagement, countering the isolation and invisibility that result from privatization. And they are making serious efforts to build social safety nets to help individuals weather transitions they encounter in the new flexible labour market.

None of the activities of citizen union organizations described above depends upon the National Labor Relations Board to certify the organization as a majority representative. Rather, the organizations function as hybrids of local-improvement civic associations and citizens' lobbying groups, emphasizing issues emanating from the workplace. Citizen unionism could supplement and support plant-level collective bargaining by individual unions in settings in which they exist. However, to truly facilitate the development of citizen unions, there would have to be many changes in the labour bargaining laws. These changes can only come about from a social movement that is informed by a vision of the possibilities for social justice in the new economy. ${ }^{59}$ There remains a question of whether local organization can transform national politics and transnational institutions. We do not yet have any empirical evidence that this can occur, but on the other hand, the localized forms of citizen bargaining described above are new and still quite small. It is thus too soon to know whether these and other experiments at the local level can devise a strategy and coalesce into an organization on the national or even transnational level that can slay the three-headed beast.

$s 9$ For a more detailed discussion of changes to labour law that would facilitate the development of citizen unions, see Stone, From Widgets to Digits, supra note 1. 